\title{
ANALISIS FAKTOR - FAKTOR YANG MEMPENGARUHI KINERJA SISTEM INFORMASI AKUNTANSI (SIA) \\ DI PT. CIPTA NIAGA SEMESTA
}

\author{
Afnil Fitri Hanafiah \\ Dewi Zulvia, SE, MM \\ Akuntansi, STIE “KBP” Padang \\ E-mail : afniel.chuniel@gmail.com
}

\begin{abstract}
Accounting information system is part of the information system, which can provide information about accounting that can support the performance of the parties - parties who use it. This study was conducted to determine whether factors consisting of user involvement (X1), personal engineering skills (X2), top management support (X3), formalization of development (X4), and training and education program (X5) can affect system performance accounting information (Y). PT.Cipta Niaga Semesta is the chosen research place and the respondents are employees who use accounting information system as many as 47 employees. This research is a quantitative research where using statistical application that is SPSS version 23. Based on result of research analysis concluded from variables used that have significant positive effect to accounting information system performance is variable of personal technique ability and formalization of information system development.
\end{abstract}

Keyword : Performance, Accounting Information System,

\section{PENDAHULUAN}

Sistem Informasi Akuntansi (SIA) merupakah salah satu bagian dari Sistem Informasi, dimana sistem informasi akuntansi juga mengalami perubahan seiring dengan berkembangnya teknologi. Sistem Informasi Akuntansi (SIA) memiliki peran yang sangat penting dalam suatu entitas baik skala kecil maupun besar (Rosita 2013). Informasi yang baik dan buruknya kinerja dalam sistem informasi akuntansi bisa dilihat dari kepuasan pemakai sistem informasi akuntansi, pihak yang menggunakan hasil dari sistem informasi akuntansi dan pemakaian dari sistem informasi itu sendiri. Sitem informasi akuntansi dapat digunakan sebagai penyedia informasi yang ditunjukan untuk pengguna laporan keuangan dalam mengambil sebuah keputusan. Sistem informasi akuntansi menghasilkan informasi keuangan yang bisa dipercaya, relevan, tepat waktu, dapat di pahami dan teruji kebenarannya untuk membantu dalam proses pengambilan keputusan ekonomis. 
Baik buruknya kinerja dari sistem informasi akuntansi yang diterapkan dapat dilihat dari segi pemakai sistem informasi akuntansi itu sendiri. Dapat dikatakannya sebuah sistem informasi itu berhasil apabila didukung oleh beberapa faktor pendukungnya. Menurut Soegiharto dan Tjai Fung Jen (Almilia and Briliantien 2007) ada beberapa faktor yang dapat mempengaruhi kinerja sistem informasi akuntansi, antara lain: keterlibatan pemakai dalam pengembangan sistem, kemampuan teknik personal, dukungan manajemen puncak, formalisasi pengembangan sistem informasi dan program pelatihan dan pendidikan pemakai sistem informasi akuntansi.

Sektor perdagang merupakan salah satu sektor yang ikut terpengaruh oleh perkembangan teknologi informasi, karena dalam beberpa hal memiliki penanan yang sangat berpotensi dalam pengembangan dan penyediaan berbagai informasi untuk dapat menyajikan segala aporan sebagai salah satu bagian pengendalian manajemen. Dalam perusahaan perdagangan, informasi merupakan hal yang sangat penting karena dapat membantu dalam operasional perusahaan tersebut. Selain memerlukan informasi yang benar, akurat dan cepat dalam pengolahannya, sistem informasi yang digunakan oleh perusahaan juga digunakan untuk memudahkan manajemen dalam melakukan pengendalian untuk pengambilan keputusan dari laporan dari segala bidang yang ada diperusahaan. Dari sistem informasi yang diterapkan dapat diketahui apakah manajemen dari organisasi tersebut bisa dikatakan baik atau tidak.

Pada penelitian ini, peneliti mengacu pada penelitian terdahulu yang sudah melakukan penelitian dengan judul yang sama, namun objek yang beda, peneliti memiliki 5 (lima) peneliti sebelumnya yaitu Dengan adanya beberapa perbedaan pada hasil penelitian yang dilakukan oleh peneliti terdahulu yaitu (Komara 2005), (Almilia \& Briliantien, 2007), (Ronaldi 2012), (Patmiati 2013) dan (Sudibyo and Kuswanto 2011).

Berdasarkan latar belakang yang telah dinyatakan diatas memberikan motivasi dan berkeinginan untuk mengetahui serta mengukur berdasarkan latar belakang yang ditemukan, penulis tertarik untuk mengangkat permasalahan tersebut kedalam sebuah penelitian yang berjudul "Analisis Faktor - Faktor Yang Mempengaruhi Kinerja Sistem Informasi Akuntansi (SIA) di PT. Cipta Niaga Semesta.

\section{Tinjauan Pustaka}

Sistem Informasi Akuntansi (SIA) termasuk bagian dari sistem informasi ini lebih menekakan pada informasi keuangan baik untuk kepentingan eksternal maupun internal. Istilah sistem informasi akuntansi (SIA) baru mulai dipopulerkan sekitar tahun 1980-an. Sebelumnya dikelan dengan nama sistem akuntansi (SA). SIA yang merupakan bagian dari sistem informasi ini lebih menekakan pada informasi keuangan baik untuk kepentingan eksternal maupun internal.

PMulyadi menjelaskan bahwa sistem akuntansi (SA) adalah organisasi formulir, catatan dan laporan yang dikoordinasikan sedemikian rupa untuk dapat 
menyediakan informasi keuangan yang dibutuhkan oleh manajemen sehingga memberikan kemudahkan pengelolaan perusahaan. Bodnar \& Hopwood memberikan pendapatnya bahwa sistem informasi akuntansi (SIA) adalah sekumpulan sumber dana dan daya (resources) seperti orang dan peralatan yang dirancangn agar dapat mentransformasi data keuangan dan data lainnya menjadi informasi. informasi ini dapat dikomunikasikan kepada pihak pengambil keputusan yang sangat beragam (Ardana \& Lukman, 2016: 45).

Menurut (Krismiaji, 2010: 4) mendefenisikan Sistem Informasi Akuntansi sebagai sebuah sistem yang memproses data dan transaksi guna menghasilkan informasi yang bermanfaat untuk merencanakan, mengendalikan, dan mengoperasikan bisnis. Sistem informasi Akuntansi terdiri tiga subsistem yang dipaparkan oleh Hall (2009: 10), tiga subsistem tersebut adalah :

a. Sistem Pemprosesan Transasksi

Dapat memberikan dukungan terhadap operasional pada setiap hari yang terdiri dari dokumen dan signal untuk pemakai yang terlibat dalam entitas.

b. Sistem Buku Besar / Pelaporan Keuangan

Hasil dari sistem ini yaitu laporan keuangan berupa laporan rugi laba, laporan perubahan ekuitas, laporan posisi keuangan dan laporan - laporan lainnya.

c. Sistem Pelaporan Manajemen

Sistem ini menyediakan informasi yang dapat digunakan untuk kepentingan manajemen internal dalam mengambil keputusan.

\section{Kinerja Sistem Informasi Akuntansi}

Dalam penelitian Soegiharto (Almilia and Briliantien 2007) mengukur kinerja sistem informasi akuntansi dari sisi pemakai dengan membagi ke dalam dua bagian yaitu kepuasan pemakai informasi dan pemakaia informasi.

a. Kepuasan pemakai sistem informasi, ketika sebuah sistem informasi diperlukan, penggunaan sistem akan menjadi kurang dan kesusksesan manajemen dengan sistem informasi dapat menetukan kepuasan pemakai.

b. Pemakaian sistem informasi akuntansi, penentuan keberhasilan komputer adalah tidak berdiri sendiri sehingga pemakaian sistem digunakannya untuk melakukan penelitian mengenai sistem informasi

\section{Faktor - faktor Yang Perlu Dipertimbangkan Dalam Perencangan Sistem Informasi Akuntansi}

Perencangan sistem informasi untuk suatu perusahaan perlu mempertimbangkan beberapa faktor yang dianggap penting (Nurharisma 2010), adalah sebagai berikut:

a. Cepat, merupakan sebuah sistem informasi akuntansi yang dirancang untuk dapat menyediakan informasi yang dibutuhkan tepat pada waktunya, dapat memberikan kebutuhan akan informasi dan memberikan kualitas informasi yang sesuai. 
b. Aman, suatu sistem informasi akuntansi yang dirancang harus bisa membantu untuk menjaga keamanan aset milik perusahaan. untuk itu dalam penyusunan harus mempertimbangkan tingkat keamanan informasi tesebut.

c. Murah, biaya pengadaaan sebuah sistem informasi akuntansi yang digambarkan, semaksimal mungkin dapat ditekan agar bisa lebih relatif ekonomis dan tidak mahal jika dibandingkan dengan kualitas informasi yang dapat dihasilkan.

d. Layanan, sebuah sistem informasi akuntansi yang dirancang tidak mengurangi kualitas layanan perusahaan kepada pihak -pihak luar seperti pelanggan, nasabah, penyimbanan dan investor.

Dari keempat faktor tersebut harus dipertimbangan secara bersama - sama pada waktu merancang sistem informasi akuntansi sehingga tidak sampai terjadi adanya salah satu faktor yang ditinggalkan atau hanya mementingkan salah satu dari beberapa faktor saja.

\section{Faktor - Faktor Yang Mempengaruhi Kinerja Sistem Informasi Akuntansi}

Dari penelitian yang sudah dilakukan, ada beberapa faktor yang mempengaruhi kinerja sistem informasi akuntansi adalah sebagai berikut:

1. Keterlibatan pemakai dalam proses pengembangan sistem

Keterlibatan mempengaruhi kriteria kunci seperti kualitas sistem, kepuasan pengguna dan penggunaaan sistem oleh Iven dan Olson, Bruver serta Hirschelm (Komara 2005). Menurut mereka bahwa keterlibatan pengguna / pemakai dalam proses pengambangan sistem mempunyai pengaruh terhadap kepuasaan atas Computerize Baser Information System (CBIS).

2. Kemampuan teknik personal

Pemakai sistem informasi yan memiliki kemampuan yang diperoleh dari pendidikan dan pengalaman akan meningkakan kepuasan dalam menggunakan SIA dan akan terus menggunakannya dalam membantu menyelesaikan pekerjaannya karena pemakai memiliki pengetahuan dan kemampuannya yang memadai.

3. Dukungan manajemen puncak

Manajemen puncak atau disebut Top Management sebagai pihak yang bertanggung jawab atas keberhasilan semua kegiatan yang berhubungan dengan sistem informasi yang akan menyediakan pedoman bagi kegiatan informasi agar pengguna sistem tidak mendapatkan kesulitan dalam mengoperasikan sistem tersebut. Pihak manajemen puncak juga memiliki kemahiran dalam mengguakan komputer sehingga para pengguna sistem informasi tidak merasa kesulitan apabila menemukan permasalahan pada sistem informasi yang digunakan dan secara langsung mendapatkan respon atau solusi dari pihak manajemen atas masalah tersebut sehingga membuat pengguna sistem merasa mendapatkan kepuasan.

4. Formalisasi pengembangan sistem 
Formalisasi pengembangan sistem memiliki hubungan dengan keberhasilan sistem informasi. Hal in juga dijelaskan dari penelitian yang dilakukan Neal dan Reader yang dikutip oleh (Rusdi and Megawati 2007) menunjukan hubungan positif antara riset operasional atau keberhasilan suatu manajemen sains dan formalisasi dengan prosedur riset operasi atau manajemen sains.

5. Pelatihan dan pendidikan pemakai

Dengan pelatihan dan pendidikan, pengguna bisa mendapatkan kemampuan untukk mengidentifikasi persyaratan informasi mereka dan kesungguhan serta keterbatasan sistem informasi dan kemampuan ini dapat mengarah pada peningkatan kinerja menurut Montazemi (Komara 2005).

\section{Hipotesis}

Berdasarkan model penelitian yang dilakukan oleh peneliti sebelumnya, peneliti memilih 5 (lima) penelitian sebelumnya yang sama - sama mengangkat judul tentang faktor - faktor yang dapat mempengaruhi kinerja sistem informasi akuntansi. Penelitian yang dilakukan(Komara 2005) dengan sampel perusahaan menufaktur skala menengah dan besar, (Almilia and Briliantien 2007) dengan sampelnya bank umum pemerintah, (Ronaldi 2012) dengan sampel perusahaan penyedia jasa taxi, (Patmiati 2013) dengan sampel perusahaan pengolahan kapas dan (Sudibyo and Kuswanto 2011) dengan sampel bank perkreditasn rakyat. Hippotesis yang diambil untuk penelitian ini adalah sebagai berikut :

1. H1 Keterlibatan pemakai dalam proses pengembangan sistem berpengaruh positif terhadap kinerja sistem informasi akuntasi

2. H2 Kemampuan teknik personal berpengaruh positif terhadap kinerja sistem informasi akuntansi

3. H3 Dukungan manajemen puncak berpengaruh positif terhadap kinerja sistem informasi akuntansi

4. H4 Formalisasi pengembangan sistem berpengaruh positif terhadap kinerja sistem informasi akuntansi

5. H5 Program pelatihan dan pendidikan pengguna berpengaruh positif terhadap kinerja sistem informasi lebih tinggi

\section{METODE PENELITIAN}

Penelitian ini merupakan penelitian kuantitatif dengan jenis penelitian interval. Peneliti memiliki tempat penelitian yaitu PT. Cipta Niaga Semesta dan yang menjadi sampel penelitian adalah karyawan / staff perusahaan yang menggunakan sistem informasi akuntansi berjumlah 47 Orang dan menyebarkan kuesioner untuk dapat diisi dengan baik dan benar.

Teknik uji yang digunakan dalam penelitian ini menggunakan beberapa uji sebagai berikut : 
1. Uji Validitas, digunakan untuk menguji apakah indikator - indikator dari variabel benar - benar mengukur variabel yang dimaksud secara nyata (Johan 2017), pada uji ini menggunakan teknik KMO (Kaiser - Mayer - Olkin) and Bartlett's Test. Pada uji ini dapat disimpulkan jika nilai KMO yang diperoleh berkisar dari $0-1$, semakin mendekati angka 1 berarti semakin bagus, nilai yang dapat diterima adalah diatas 0,05 .

2. Uji Reliabilitas, dilakukan terhadap masing-masing variabel secara terpisah. Ini dilakukan menggunakan teknik cronbach's alpha yang mengindentifikasi internal konsistensi antar indikator dalam mengukur variabel. Pada uji ini dapat disimpulkan jika variabel tersebut reliabel dilihat dari nilai cronbach's alpha yang dihasilkan adalah diatas 0,6 .

3. Uji Asumsi Klasik, pada uji asumsi klasik ini terdapat 3 uji yaitu :

a. Uji normalitas, uji normalitas ini adalah uji data dengan Kolmoggorov Smirnov, dilakukan untuk mengindentifikasi data yang diperoleh berdistribusi normal, data yang berdistribusi normal dianggap mewakili populasi secara lebih akurat dan presisi. Data dapat dikatakan berdistribusi normal jika nilai probabilitas yang dihasilkan diatas 0,05 sedangkan nilai probabilitas dibawah 0,05 dapat dikatakan jika data tersebut tidak berdistribusi normal.

b. Uji Multikolinearitas ini dilakukan untuk mengindentifikasi apakah terdapat hubungan yang sangat kuat antar vaiabel independen. Pada uji ini dilakukan sejalan dengan uji regresi linear berganda dimana akan mendapatkan nilai tolerance dan nilai VIF. Data dapat dikatakan tidak terjadi multikolinearitas jika nilai tolerance yang didapat < (kecil ) dari 0,1 dan nilai VIF > (besar) dari 10.

c. Uji Heteroskedastisitas dengam metode Glejser dan P-Plot, ini dilakukan untuk mengindentifikasi apakah error term yang muncul pada setiap pengukuran dari variabel independen terhadap variabel dependen yang bersifat konstanta. apabila tidak adanya kesamaan deviasi standar nilai variabel dependen pada setiap variabel independen dan tidak terjadinya heteroskredastisitas dapat dilihat dengan pola titik yang dihasilkan pada metode P-Plot. Pada metode Glejse, uji heteroskedastisitas ini ditunjukan dengan nilai signifikan lebih besar dari 0,05 sehingga data tersebut dapat dikatakan tidak terjadi heteroskedastisitas dan jika terjadi heteroskedastisitas maka nilai signifikan yang didapat lebih kecil dari 0,05.

4. Uji Analisis Regresi Linear Berganda berganda, ini untuk menguji hubungan anatara dua variabel yaitu independen dan dependen. Jika hanya terdapat satu variabel dependen dan independen, pengujian disebut uji regresi sederhana, dan jika terdapat lebih dari satu variabel independen yang diuji terhadap satu variabel dependen maka pengujian disebut dengan uji regresi linear berganda. Pada uji ini akan menghasilkan uji hipotesis berupa Uji T, Uji F dan Uji Koefisien Determinasi $\left(\mathrm{R}^{2}\right)$.

5. Uji Hipotesis F, pada uji $\mathrm{F}$ ini akan menunjukan hasil penelitian apakah terdapatnya pengaruh secara simultas pada variabel independen terhadap 
variabel dependen. Pada uji ini yang dilihat adalah nilai signifikan yang dapat diterima kecil dari 0,05 .

6. Uji Hipotesis $\mathrm{T}$, pada uji $\mathrm{T}$ ini akan menunjukan hasil penelitian apakah terdapatnya pengaruh secara parsial atau terpisah antara variabel independen terhadap variabel dependen. Pada uji ini yang dilihat adalah nilai signifikan yang dapat diterima kecil dari 0,05. Sehingga pada uji hipotesis T ini dapat menjawab rumusan masalah yang diangkatkan dan menganalisis hipotesis yang dibuat.

7. Uji Koefisien Determinasi $\left(\mathrm{R}^{2}\right)$, besarnya koefisien determinasi ditunjukan dengan nilai Adjusted R Square, dengan nilai koefisien determinasi antara 0 1. Bila nilai koefisien determinasi sama dengan 0 , artinya variabel dari Y tidak dapat diterangkan oleh $\mathrm{X}$ sama sekali. Bila nilai determinasi 1, maka semua titik pengamatan berada tepat pada garis regresi. Dengan demikian baik atau burunya suatu persamaan regresi ditentukan oleh Determinasi $\left(\mathrm{R}^{2}\right)$

\section{HASIL DAN PEMBAHASAN}

Penelitian ini menggunakan kuesioner yang telah disebar kepada seluruh staff / karyawan PT. Cipta Niaga Semesta sebanyak 47 Orang dan seluruh kuesioner yang dikembalikan layak untuk diolah menggunakan program statistik SPSS versi 23. PT. Cipta Niaga Semesta merupakan perusahaan anak dari PT. Mayora Tbk, dimana perusahaan ini merupakan perusahaan dagang yang mendistribusikan produk - produk yang dihasilkan oleh perusahaan induknya PT. Mayora Tbk yang berkantor pusat di Jakarta. PT. Cipta Niaga Semesta berlokasi di Jl. By Pass KM 19,5 Kel. Tanjung Aur Kec. Koto Tangah Lubuk Minturun, Padang - Sumatera Barat.

\section{Uji Validitas}

Berdasarkan hasil pengujian pada item pertanyaan dalam kuesioner dengan menggunakan metode KMO (Kaiser - Mayer - Olkin) and Bartlett's Test. Hasil yang didapat dapat bahwa nili KMO mendapatkan hasil 0,549 dengan signifikan $0,000<0,05<0,01$ sehingga dapat disimpulkan bahwa data kuesioner tersebut dapat diterima atau valid.

\section{Uji Reliabilitas}

Berdasarkan hasil pengujian reliabilitas dengan menggunakan teknik cronbach's alpha pada setiap variabel yang digunakan. Nilai yang didapat pada keenam variabel yang digunakan dalam penelitian dapat dilihat pada tabel berikut:

Tabel 1

\section{Hasil Uji Reabilitas}

\begin{tabular}{|l|l|c|c|c|}
\hline No. & \multicolumn{1}{|c|}{ Variabel } & Nilai $\alpha$ & Reliabilitas & Keterangan \\
\hline 1. & $\begin{array}{l}\text { Keterlibatan pengguna / } \\
\text { pemakai (X1) }\end{array}$ & 0,770 & 0,600 & Reliabel \\
\hline
\end{tabular}




\begin{tabular}{|l|l|c|c|c|}
\hline 2. & $\begin{array}{l}\text { Kemempuan Personal } \\
\text { 3. }\end{array}$ & $\begin{array}{l}0,734 \\
\text { Makungan (X2) } \\
\text { 4. }\end{array}$ & $\begin{array}{l}\text { Formalisasi (X3) } \\
\text { Pengembangan SI (X4) } \\
\text { 5. }\end{array}$ & $\begin{array}{l}\text { Program Pendidikan dan } \\
\text { Pelatihan (X5) }\end{array}$ \\
6. & $\begin{array}{l}\text { Kinerja SIA (Y) } \\
\text { Sumber : } \quad \text { Data }\end{array}$ & 0,7900 & Reliabel \\
\hline
\end{tabular}

Berdasarkan tabel 1 hasil uji reabilitas diatas, dapat dijelaskan bahwa dari 6 (enam) variabel yang digunakan mendapatkan nilai reabilitasnya melebihi dari batas minimum yang ditentukan yaitu besar dar 0,600, masing - masing variabel tersebut adalah keterlibatan pengguna / pemakai dalam proses pengembangan sistem $\left(\mathrm{X}_{1}\right)$ 0,770, kapabilitas personal $\left(\mathrm{X}_{2}\right)$ 0,734, dukungan manajemen puncak $\left(\mathrm{X}_{3}\right)$ 0,730, formalisasi pengembangan sistem $\left(\mathrm{X}_{4}\right)$ 0,791, Pelatihan dan Pendidikan Pengguna ( $\left.\mathrm{X}_{5}\right)$ 0,757 dan kinerja sistem informasi (Y) 0,869 menunjukan hasil cronbach's alpha $>0,600$, sehingga dapat disimpulkan bahwa variabel yang digunakan adalah reliabel.

\section{Uji Asumsi Klasik}

\section{a. Uji Normalitas}

Pada uji normalitas ini menggunakan Kolmoggorov - Smirnov sehingga hasil yang diperoleh adalah harus mendapatkan nilai siginifikan lebih besar dari 0,05 sehingga dapat disimpulkan bahwa data menyebar / berdistribusi secara normal. Hasil uji normalitas ini dapat dilihat pada tabel hasil uji yang dilakukan sebagai berikut:

Tabel 2

\section{Hasil Uji Normalitas}

\begin{tabular}{|ll|r|}
\hline & & \multicolumn{2}{|c|}{$\begin{array}{c}\text { Standardized } \\
\text { Residual }\end{array}$} \\
\hline $\mathrm{N}$ & Mean & 47 \\
Normal &, 0000000 \\
Parameters & Std. &, 94408916 \\
& Deviation &, 111 \\
Most Extreme & Absolute &, 071 \\
Differences & Positive &,- 111 \\
& Negative &, 111 \\
Test Statistic & &, $192^{\mathrm{c}}$ \\
Asymp. Sig. (2-tailed) & \\
\hline
\end{tabular}

Sumber : Data Diolah, 2018

Berdasarkan tabel diatas dapat dilihat bahwa nilai Asymp. Signifikan yang didapat adalah 0,192 lebih besar dari 0,05 sehingga dapat disimpulkan bahwa data yang diuji pada asumsi klasik dengan uji normalitas menggunakan 
Kolmoggorov - Smirnov dapat berdistribusi normal sehingga bisa melakukan uji lainnya dan menarik kesimpulan dari data tersebut.

\section{b. Multikolinearitas}

Dari hasil yang didapat pada uji multikolinearitas dapat disimpulkan bahwa masing - masing variabel yang digunakan tidak terjadinya multikolinearitas. Ini dibuktikan dengan didapatnya nilai VIF $<10$ dan nilai tolerance $>0,10$. Hasil dari uji multikolinearitas ini dapat dilihat pada tabel hasil uji

multikolinearitas

berikut

Tabel 3

Hasil Uji Multikolinearitas

\begin{tabular}{|c|c|c|c|}
\hline Variabel & Tolerance & VIP & Keterangan \\
\hline X1 & 0,874 & 1,145 & Tidak Terjadi Multikolinearitas \\
\hline X2 & 0,982 & 1,018 & Tidak Terjadi Multikolinearitas \\
\hline X3 & 0,850 & 1,176 & Tidak Terjadi Multikolinearitas \\
\hline X4 & 0,916 & 1,092 & Tidak Terjadi Multikolinearitas \\
\hline X5 & 0,895 & 1,117 & Tidak Terjadi Multikolinearitas \\
\hline
\end{tabular}

\section{Sumber : Data Diolah, 2018}

Berdasarkan hasil yang di dapat pada tabel diatas menjelaskan, bahwa 5 (lima) variabel independen (X) yang digunakan benar tidak terjadi multikolinearitas ini didukung bahwa masing - masing variabel mendapatkan nilai tolerance dan VIP sesuai dengan ketentuan. Pada X1 nilai tolerance yang didapat adalah $0,874>0,10$ sedangan nilai VIP $1,145<10$, untuk X2 nilai tolerance yang didapat adalah $0,982>0,10$ sedangan nilai VIP $1,018<$ 10, X3 mendapatkan nilai tolerance yang didapat adalah $0,850>0,10$ sedangan nilai VIP $1,176<10$, X4 juga mendapatkan nilai tolerance yang didapat adalah 0,916>0,10 sedangan nilai VIP 1,092 < 10 dan terakhir adalah X5 nilai tolerance yang didapat adalah $0,895>0,10$ sedangan nilai VIP 1,117 $<$

\section{c. Heteroskedastisitas}

Uji heteroskedastisitas yang dilakukan dengan menggunakan uji glejser dan scatterplot. Pada uji glejser hasil yang didapat bahwa nilai signifikansi > 0,05 dapat dijelaskan nilai yang didapat oleh masing - masing variabel pada tabel berikut :

Tabel 4

Uji Heteroskredastisitas (Glejser)

\begin{tabular}{|l|r|}
\hline \multicolumn{1}{|c|}{ Variabel } & \multicolumn{2}{|c|}{ Signifikansi } \\
\hline Keterlibatan Pemakai &, 787 \\
Kemampuan Teknik Persoanl &, 172 \\
Dukungan Manajemen Puncak &, 426 \\
Formalisasi Pengembangan Sistem &, 738 \\
Program Pelatihan dan Pendidikan &, 357 \\
\hline
\end{tabular}

Sumber : Data Diolah, 2018. 
Berdasarkan tabel diatas menjelaskan hasil uji heteroskredastisitas dimana masing - masing variabel yaitu variabel variabel keterlibatan pengguna / pemakai dalam proses pengembangan sistem $\left(\mathrm{X}_{1}\right)$ mendapatkan hasil sig $0,787>0,05$, kemampuan teknik personal $\left(\mathrm{X}_{2}\right)$ mendapatkan hasil sig $0,172>$ 0,05 , dukungan manajemen puncak $\left(\mathrm{X}_{3}\right)$ mendapatkan hasil sig 0,426 $>0,05$, formalisasi pengembangan sistem $\left(\mathrm{X}_{4}\right)$ mendapatkan hasil sig 0,738 $>0,05$ dan Pelatihan dan Pendidikan Pengguna $\left(\mathrm{X}_{5}\right)$ mendapatkan hasil sig 0,357 > 0,05 dengan nilai yang didapat disimpulkan bahwa variabel yang diuji dengan metode glejser dapat dikatakan tidak terjadi heteroskedastisitas.

Begitu dengan uji scatterplot yang menggambarkan titik-titik menyebar diatas dan dibawah atau sekitarar angka 0 (nol) dan tidak membuat pola tertentu sehingga menandakan tidak terjadinya heteroskedastisitas berikut adalah gambar hasil uji scatterplot.

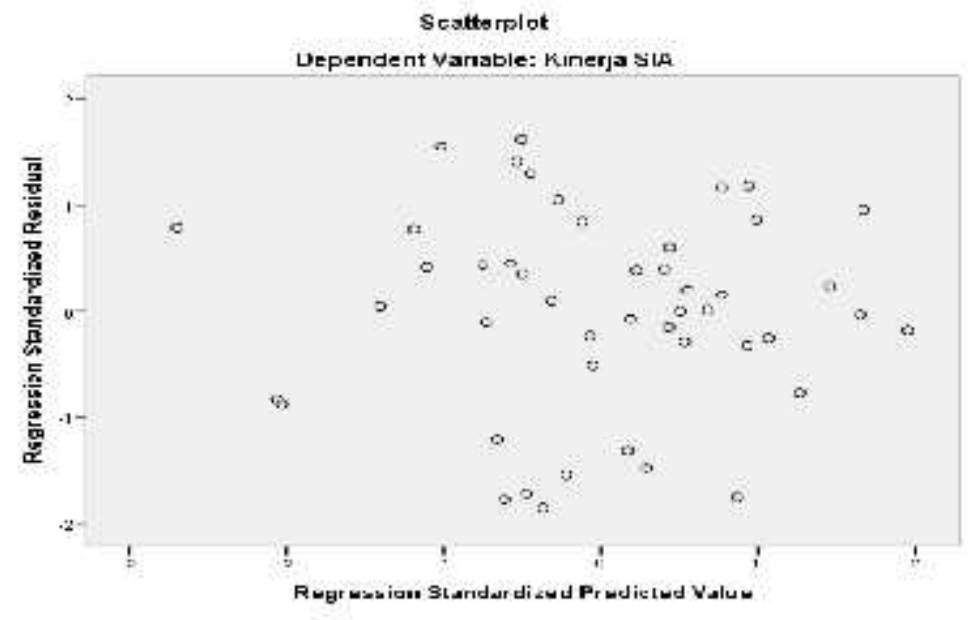

Gambar 1 Uji scatterplot

\section{Uji Analisis Regresi Berganda}

Hasil yang didapat pada uji analisis regresi berganda di dapat persamaan regresi linear berganda yaitu :

$$
Y=13,731-0,576 X_{1}+3,516 X_{2}+0,256 X_{3}+0,442 X_{4}+0,357 X_{5}+e
$$

\section{Uji Hipotesis F}

Uji $\mathrm{F}$ merupakan uji yang menjelaskan bahwa variabel independen berhubungan simultan / secara bersama - sama terhadap variabel dependen. Pada uji $\mathrm{F}$ hasil yang diperoleh adalah nilai $\mathrm{F}$ hitung 16,969 dengan nilai signifikan 0,000 , dengan nilai signifikansi $0,000<0,05$ sehingga dapat disimpulkan bahwa variabel independen (X) yaitu keterlibatan pengguna / pemakai dalam proses pengembangan sistem, kapabilitas personal, dukungan manajemen puncak, 
formalisasi pengembangan sistem, Pelatihan dan Pendidikan Pengguna berpengaruh secara simultan atau secara bersama - sama berpengaruh terhadap variabel dependen (Y) yaitu kinerja sistem informasi akuntansi.

\section{Uji Hipotesis T}

Berdasarkan hasil uji $\mathrm{T}$ yang dilakukan terhadap 5 (lima) variabel independen yang digunakan dalam penelitian untuk melihat pengaruh masingmasing variabel independen $(\mathrm{X})$ terhadap variabel dependen $(\mathrm{Y})$ dapat dilihat pada tabel berkikut:

Tabel 5

Hasil Uji Hipotesis T

\begin{tabular}{|ll|c|c|}
\hline \multicolumn{1}{|c|}{ Model } & $\mathrm{T}$ & Sig \\
\hline 1 (Constant) & 1,593 &, 119 \\
& Keterlibatan Pemakai & $-1,676$ &, 101 \\
& Kemampuan Personal &, 000 \\
& $\begin{array}{l}\text { Dukungan Manajemen } \\
\text { Puncak }\end{array}$ & 1,357 &, 247 \\
& $\begin{array}{l}\text { Formalisasi } \\
\text { Pengembangan SI }\end{array}$ & 2,218 &, 032 \\
$\begin{array}{l}\text { Program Pelatihan dan } \\
\text { Pendidikan }\end{array}$ & 1,126 &, 267 \\
\hline
\end{tabular}

Sumber

:

Data

Diolah,

Dari tabel diatas dapat menjelaskan, dari 5 (lima) variabel independen (X) yang digunakan hanya 2 (dua) variabel independen (X) memberikan hasil berpengaruh positif signifikan terhadap variabel dependen (Y) yaitu kemampuan teknik personal (X2) dan Formalisasi Pengembangan SI (X4). Hasil yang didapat adalah variabel X2 mendapakan nilai signifikan $0,000<0,05$ dan X4 mendapat nilai signifikan $0,032<0,05$. Untuk daPat melihat hasil yang didapat pada uji $\mathrm{T}$ dapat dilihat tabel berikut.

\section{Uji Koefisien Determinasi $\left(\mathbf{R}^{2}\right)$}

Uji ini dilakukan untuk mengetahui seberapa besar variabel independen (X) yang digunakan dalam penelitian dapat menjelaskan tentang variabel dependen (Y). Hasil uji koefisien determinasi dapat dilihat pada tabel berikut : 
Tabel 6

Hasil Uji Koefisien Determinasi $\left(\mathbf{R}^{2}\right)$

\begin{tabular}{|l|l|l|l|l|}
\hline Model & $\mathrm{R}$ & R Square & $\begin{array}{l}\text { Adjusted R } \\
\text { Square }\end{array}$ & $\begin{array}{l}\text { Std. Error of the } \\
\text { Estimate }\end{array}$ \\
\hline 1 &, $821^{\mathrm{a}}$ &, 674 &, 634 & 3,936 \\
\hline a. Predictors: (Constant), Program Pelatihan dan \\
$\begin{array}{l}\text { Pendidikan, Kemampuan Personal, Formalisasi } \\
\text { Pengembangan SI, Keterlibatan Pemakai, Dukungan } \\
\text { Manajemen Puncak }\end{array}$
\end{tabular}

\section{Sumber : Data Diolah, 2018}

Hasil yang didapat pada uji koefisien determinasi pada tabel diatas dapat disimpulkan bahwa 5 (lima) variabel $\mathrm{X}$ yang digunakan yaitu keterlibatan pengguna / pemakai dalam proses pengembangan sistem, kapabilitas personal, dukungan manajemen puncak, formalisasi pengembangan sistem, Pelatihan dan Pendidikan dapat menjelaskan sebesar $63,4 \%$ tentang kinerja sistem informasi akuntansi dan selebihnya dapat dijelaskan oleh variabel lain yang tidak digunakan dalam

penelitian

ini.

\section{Pembahasan}

Hasil uji yang telah didapat terhadap variabel yang digunakan dalam penelitian yaitu, keterlibatan pengguna / pemakai dalam proses pengembangan sistem $\left(\mathrm{X}_{1}\right)$, kapabilitas personal $\left(\mathrm{X}_{2}\right)$, dukungan manajemen puncak $\left(\mathrm{X}_{3}\right)$, formalisasi pengembangan sistem $\left(\mathrm{X}_{4}\right)$ dan Pelatihan dan Pendidikan Pengguna $\left(\mathrm{X}_{5}\right)$ sebagai variabel independen dan kinerja sistem informasi akuntansi $(\mathrm{Y})$ sebagai variabel dependen. Dapat disimpulkan bahwa faktor kapabilitas personal $\left(\mathrm{X}_{2}\right)$ dan formalisasi pengembangan sistem $\left(\mathrm{X}_{4}\right)$ yang berpengaruh posiif dan signifikan terhadap kinerja sistem informasi akuntansi (Y).

Keterlibatan pemakai tidak berpengaruh signifikan terhadap kinerja sistem informasi akuntansi secara parsial. Hasil penelitian ini tidak mendukung penelitian yang dilakukan oleh (Komara 2005), (Ronaldi 2012), (Patmiati 2013) dan (Sudibyo and Kuswanto 2011) karena penelitian tersebut sama - sama menyimpulkan bahwa keterlibatan pengguna dalam pengembangan sistem berpengaruh terhadap kinerja sistem informasi. Hasil penelitian ini mendukung penelitian yang dilakukan oleh (Almilia and Briliantien 2007) bahwa keterlibatan pengguna dalam pengembangan sistem tidak berpengaruh terhadap kinerja sistem informasi.

Kemampuan teknik personal berpengaruh signifikan terhadap kinerja sistem informasi akuntansi secara parsial. Hasil penelitian ini mendukung penelitian yang dilakukan oleh (Komara 2005), (Patmiati 2013) dan (Sudibyo and Kuswanto 2011) yang sama - sama menyimpulkan bahwa kemampuan teknik 
personal berpengaruh signifikan terhadap kinerja sistem informasi akuntansi. Dan hasil penelitian ini tidak mendukung penelitian yang dilakukan (Ronaldi 2012) dan (Almilia and Briliantien 2007) yang menyimpulkan bahwa kemampuan teknik personal tidak berpengaruh signifikan terhadap kinerja sistem informasi akuntansi.

Dukungan manajemen puncak tidak berpengaruh signifikan terhadap kinerja sistem informasi akuntansi secara parsial. Hasil penelitian ini tidak mendukung penelitian yang dilakukan peneliti sebelumnya yaitu oleh (Komara 2005), (Patmiati 2013) , (Sudibyo and Kuswanto 2011) yang sama - sama menyimpulkan bahwa dukungan manajemen puncak berpengaruh terhadap kinerja sistem informasi akuntansi. Namun, hasil penelitian ini mendukung penelitian sebelumnya yang dilakukan oleh (Ronaldi 2012) dan (Almilia and Briliantien 2007) menyimpulkan bahwa dukungan manajemen puncak tidak berpengaruh terhadap kinerja sistem informasi akuntansi.

Formalisasi pengembangan sistem informasi berpengaruh signifikan terhadap kinerja sistem informasi akuntansi secara parsial. Hasil penelitian ini mendukung penelitian yang dilakukan peneliti sebelumnya yaitu oleh, (Patmiati 2013) , (Sudibyo and Kuswanto 2011) dan (Ronaldi 2012) yang sama - sama menyimpulkan bahwa kemampuan teknik personal berpengaruh terhadap kinerja sistem informasi akuntansi. Sedangkan hasil penelitian ini bertolak belakang atau tidak mendukung penelitian yang dilakukan oleh (Komara 2005) dan (Almilia and Briliantien 2007) yang sama - sama menyimpulkan bahwa formalisasi pengembangan sistem informasi tidak pengaruh terhadap kinerja sistem informasi akuntansi.

Program pelatihan dan pendidikan tidak berpengaruh signifikan terhadap kinerja sistem informasi akuntansi secara parsial. Hasil penelitian ini tidak mendukung penelitian yang dilakukan peneliti sebelumnya yaitu oleh, (Patmiati 2013) dan (Sudibyo and Kuswanto 2011) yang sama - sama menyimpulkan bahwa program pelatihan dan pendidikan dan (Ronaldi 2012) yang sama - sama menyimpulkan bahwa program pelatihan dan pendidikan berpengaruh signifikan terhadap kinerja sistem informasi akuntansi. Sedangkan hasil penelitian ini mendukung penelitian yang dilakukan oleh (Komara 2005), (Almilia and Briliantien 2007) dan (Ronaldi 2012) yang sama - sama menyimpulkan bahwa program pelatihan dan pendidikan tidak pengaruh terhadap kinerja sistem informasi akuntansi, karena cendrung sama baik ada atau tidaknya program pelatihan dan pendidikan.

\section{KESIMPULAN}

Faktor - faktor yang mempengaruhi kinerja sistem informasi akuntansi yaitu keterlibatan pengguna / pemakai dalam proses pengembangan sistem $\left(\mathrm{X}_{1}\right)$, kapabilitas personal $\left(\mathrm{X}_{2}\right)$, dukungan manajemen puncak $\left(\mathrm{X}_{3}\right)$, formalisasi pengembangan sistem $\left(\mathrm{X}_{4}\right)$ dan Pelatihan dan Pendidikan Pengguna $\left(\mathrm{X}_{5}\right)$ menunjukan hasil berpengaruh secara simultan, Namun secraa parsial hanya faktor Kapabilitas personal $\left(X_{2}\right)$ dengan nilai sigifikan $0,000>0,05$ dan formalisasi pengembangan sistem $\left(\mathrm{X}_{4}\right)$ dengan nilai sigifikan $0,032>0,05$ yang 
berpengaruh positif dan signifikan terhadap kinerja sistem informasi akuntansi (Y). Kelima variabel atau faktor tersebut mampu menjelaskan kinerja sistem informasi akuntansi sebesar $63,4 \%$ dan lebih tidak dapat dijelaskan oleh variabel lain yang tidak digunakan dalam penelitian ini.

\section{UCAPAN TERIMA KASIH}

Pada kesempatan ini, penulis hendak menyampaikan terima kasih kepada semua pihak yang telah memberikan dukungan dan masukan sehingga artikel penelitian ini dimana artikel penelitian ini merupakan ringkasan dari skripsi yang sudah diselesaikan. Ucapan terima kasih ini penulis sampaikan kepada :

1. Bapak Febryandhie Ananda, SE, M.Si selaku ketua STIE 'KBP’ Padang.

2. Ibuk Lidya Martha, SE, MM selaku wakil ketua STIE 'KBP' Padang.

3. Ibuk Dewi Zulvia, SE, MM selaku Ketua Prodi Jurusan Akuntansi

4. Ibuk Dewi Zulvia, SE, MM selaku dosen pembimbing dalam penyusunan skripsi

5. Staff dosen serta karyawan/karyawati STIE 'KBP' Padang

6. Pimpinan Regional beserta staff / karyawan PT. Cipta Niaga Semesta Padang

\section{DAFTAR PUSTAKA}

Almilia, Luciana Spica, and Irmaya Briliantien. 2007. "Faktor-Faktor Yang Mempengaruhi Kinerja Sistem Informasi Akuntansi Pada Bank Umum Pemerintah Di Wilayah Surabaya Dan Sidoarjo." : 1-7.

Ardana, I Cenik, and Hendra Lukman. 2016. Sistem Informasi Akuntansi. Pertama. Jakarta: Mitra Wacana Media.

Hall, James A. 2009. Accounting Information System. Jakarta: Salemba Empat.

Johan, Arief Prima. 2017. "Modul Pelatihan Statistik (SPSS)." : 1-55.

Komara, Acep. 2005. "Analisis Faktor-Faktor Yang Mempengaruhi Kinerja Sistem Informasi Akuntansi." (September): 836-48.

Krismiaji. 2010. Sistem Informasi Akuntansi. Yogyakarta: UPP STIM YKPN.

Nurharisma, Rhima. 2010. "Faktor - Faktor Yang Mempengaruhi Kinerja Sistem Informasi Akuntansi." : 1-12.

Patmiati, Eni. 2013. "Faktor - Faktor Yang Mempengaruhi Kinerja Sistem Informasi Akuntansi Pada PT. Kasa Husada Wira Jatim."

Ronaldi, Hendra. 2012. “Analisis Faktor-Faktor Yang Mempengaruhi Kinerja Sistem Informasi Akuntansi." 1(3): 1-9.

Rosita. 2013. “Analisis Faktor-Faktor Yang Mempengaruhi Minat ( Studi Empiris 
Pada Ukm Di Kabupaten Karanganyar ).” 29: 1-14.

Rusdi, Dedi, and Nurul Megawati. 2007. "Analisis Faktor-Faktor Yang Mempengaruhi Kinerja Sistem Informasi Akuntansi (SIA).” : 1-18.

Sudibyo, Sukemi Kamto, and Hedy Kuswanto. 2011. "Analisis Faktor-Faktor Yang Mempengaruhi Kinerja Sistem Informasi Akuntansi Pada PT. BPR Weleri Makmur Jawa Tengah."

Zulvia, Dewi, and Nila Sari. 2017. "Analisis Sistem Informasi Akuntansi Penjualan Kredit Pada Cv . Putra Tunas Mandiri.” Jurnal Pundi 1(1): 23-32. 